\title{
Effects of temperature and organic pollution on nutrient cycling in marine sediments
}

\author{
C. Sanz-Lázaro ${ }^{1,2}$, T. Valdemarsen ${ }^{1}$, and M. Holmer ${ }^{1}$ \\ ${ }^{1}$ Department of Biology, University of Southern Denmark, Campusvej 55, 5230 Odense, Denmark \\ ${ }^{2}$ present address: Departamento de Ciencias del Mar y Biología Aplicada, Universidad de Alicante, \\ P.O. Box 99, 03080 Alicante, Spain \\ Correspondence to: C. Sanz-Lázaro (carsanz@ua.es)
}

Received: 12 November 2014 - Published in Biogeosciences Discuss.: 5 January 2015

Revised: 13 July 2015 - Accepted: 15 July 2015 - Published: 3 August 2015

\begin{abstract}
Increasing ocean temperature due to climate change is an important anthropogenic driver of ecological change in coastal systems. In these systems sediments play a major role in nutrient cycling. Our ability to predict ecological consequences of climate change is enhanced by simulating real scenarios. Based on predicted climate change scenarios, we tested the effect of temperature and organic pollution on nutrient release from coastal sediments to the water column in a mesocosm experiment. $\mathrm{PO}_{4}^{3-}$ release rates from sediments followed the same trends as organic matter mineralization rates, increased linearly with temperature and were significantly higher under organic pollution than under nonpolluted conditions. $\mathrm{NH}_{4}^{+}$release only increased significantly when the temperature rise was above $6{ }^{\circ} \mathrm{C}$, and it was significantly higher in organic polluted compared to nonpolluted sediments. Nutrient release to the water column was only a fraction from the mineralized organic matter, suggesting $\mathrm{PO}_{4}^{3-}$ retention and $\mathrm{NH}_{4}^{+}$oxidation in the sediment. Bioturbation and bioirrigation appeared to be key processes responsible for this behavior. Considering that the primary production of most marine basins is $\mathrm{N}$-limited, the excess release of $\mathrm{NH}_{4}^{+}$at a temperature rise $>6^{\circ} \mathrm{C}$ could enhance water column primary productivity, which may lead to the deterioration of the environmental quality. Climate change effects are expected to be accelerated in areas affected by organic pollution.
\end{abstract}

\section{Introduction}

Ocean temperature rise due to climate change is considered among the most severe anthropogenic drivers of ecological change in marine systems, especially in coastal areas (Halpern et al., 2008). Sea surface temperature (SST) in marine systems is expected to rise by $0.2^{\circ} \mathrm{C}$ per decade (IPCC, 2007), but in relatively enclosed and shallow coastal areas, such as the Baltic Sea, temperature has risen much more rapidly $\left(1^{\circ} \mathrm{C}\right.$ in last decade; Mackenzie and Schiedek, 2007; Belkin, 2009) and similar rises are expected for the next decades (Doscher and Meier, 2004). In these areas, heterotrophic processes in sediments prevail due to the generally low availability of light in the seabed due to eutrophication and a high input of labile organic matter (Conley et al., 2009).

Coastal areas are climate-sensitive systems (IPCC, 2007) that play an important role in the mineralization of organic matter (OM; Middelburg et al., 1997). During mineralization, organic phosphorous $(\mathrm{P})$ and nitrogen $(\mathrm{N})$ are transformed into inorganic forms $\left(\mathrm{PO}_{4}^{3-}\right.$ and $\mathrm{NH}_{4}^{+}$, respectively). $\mathrm{OM}$ is mineralized mainly by microbial processes, which are strongly influenced by temperature (Robador et al., 2009). Consequently, climate change may affect nutrient regeneration rates in coastal ecosystems.

$\mathrm{PO}_{4}^{3-}$ can be sequestered in the sediment by adsorption to ferric (oxy)hydroxides and by forming solid ferrous phosphates (Jorgensen, 1983). Sulfides resulting from sulfate reduction may mobilize $\mathrm{PO}_{4}^{3-}$ by reducing ferric oxyhydroxides (Roden and Edmonds, 1997) and by dissolving Fe minerals containing $\mathrm{PO}_{4}^{3-}$ (Gachter and Muller, 2003). Despite the complex interactions among the $\mathrm{Fe}, \mathrm{S}$ and $\mathrm{P}$ pools, $\mathrm{PO}_{4}^{3-}$ 
release to the water column is mainly dependent on the redox conditions in the sediment surface, where oxidized $\mathrm{Fe}$ keep $\mathrm{PO}_{4}^{3-}$ immobilized. Thus seasonal increases in sediment metabolic rates due to temperature rise may lead to reducing conditions in the sediment surface, resulting in $\mathrm{PO}_{4}^{3-}$ release during summer (Jensen et al., 1995; Cowan and Boynton, 1996). Mineralized $\mathrm{N}$ is mainly released to the water column as $\mathrm{NH}_{4}^{+}$(Jorgensen, 1983). $\mathrm{NH}_{4}^{+}$can be further transformed into $\mathrm{NO}_{3}^{-}$and $\mathrm{NO}_{2}^{-}$through nitrification and end up as $\mathrm{N}_{2}$ through denitrification or anammox (Thamdrup, 2012). In contrast to $\mathrm{NH}_{4}^{+}, \mathrm{NO}_{3}^{-}$and $\mathrm{NO}_{2}^{-}, \mathrm{N}_{2}$ cannot be directly used by primary producers. Consequently denitrification results in $\mathrm{N}$ removal from the ecosystem, preventing eutrophication (Thamdrup and Dalsgaard, 2008). Marine coastal sediments play a major role in supporting primary productivity of the water column by supplying a large part of the nutrient demand for phytoplankton (Nixon, 1981; Kelly et al., 1985). Increases in sea water temperature and input of $\mathrm{OM}$ to the sediment are both expected to stimulate the release of inorganic nutrients from the sediment to the water column, which may in turn stimulate primary productivity. Nutrient increase above a certain threshold may lead to algal blooms and subsequent hypoxic or anoxic events, resulting in the deterioration of ecological status (Gray et al., 2002).

Coastal areas gather the greatest human population densities in the world, resulting in high anthropogenic pressure on coastal ecosystems. Thus, many coastal areas are subject to multiple stressors (Halpern et al., 2008) such as different kinds of pollution and global warming. Among the different types of pollution, organic pollution, also know as organic enrichment, is one of the most common in densely populated coastal areas (Islam and Tanaka, 2004). As for temperature, organic enrichment enhances sediment metabolism, mainly by stimulating anaerobic pathways and especially sulfate reduction (Valdemarsen et al., 2009). This effect is magnified when organic pollution and temperature rise co-occur (SanzLazaro et al., 2011b).

Our ability to predict the ecological consequences of climate change is enhanced by simulating realistic future scenarios. Hence, it is important to conduct experiments to elucidate not only the effects of individual drivers of ecological change but also the interactions among them, especially when the interactions among these drivers are not just additive (Falkenberg et al., 2013). Despite the current concerns surrounding global change, little research effort has been made to understand how temperature rise affects the cycling of $\mathrm{N}$ and $\mathrm{P}$ in coastal sediments (Alsterberg et al., 2012). In fact, the accuracy of predictive biogeochemical models related to the effect of climate change on the coastal eutrophication is restrained due to limited knowledge (Meier et al., 2011). Thus, to improve our forecasting capacity related to climate change, estimates of temperature-driven changes in sediment nutrient release are needed.
The aim of this work is to examine the effects of temperature rise and organic enrichment on sediment nutrient release derived from heterotrophic processes. We used a mesocosm approach and hypothesized that temperature rise due to climate change increases $\mathrm{PO}_{4}^{3-}$ and $\mathrm{NH}_{4}^{+}$release from the sediments as a consequence of increased metabolic rates. We expected an increase in the release of nutrients with temperature, with a more marked effect in organically enriched than in nonorganically enriched sediments, due to the stimulation of anaerobic processes resulting in $\mathrm{PO}_{4}^{3-}$ and $\mathrm{NH}_{4}^{+}$release.

\section{Materials and methods}

This experiment is the second part of a study. The results on carbon and sulfur cycles are presented in Sanz-Lázaro et al. (2011b), where detailed information on the methods it is given.

\subsection{Collection of sediment and polychaetes}

The sediment used for experiments was well-sorted, organically poor, Fe-rich sand $(0.4 \% \mathrm{DW}$ (dry weight) particulate organic carbon (POC), $125 \mu \mathrm{mol} \mathrm{cm}{ }^{-3}$ reactive Fe with $220 \mu \mathrm{m}$ average grain size) collected at a depth of $1 \mathrm{~m}$ in Fænø Sund, Denmark (for further details see Valdemarsen et al., 2009). The macrofaunal organism used for experiments was the polychaete Nereis diversicolor, which was chosen based on its ability to bioirrigate surface sediment and influence microbial reaction rates (Kristensen, 2000; MermillodBlondin et al., 2004). N. diversicolor was collected from Fællesstrand in the outer part of Odense Fjord, Denmark.

\subsection{Experimental setup}

Sediment was split into either control $(-\mathrm{OM})$ or organically enriched sediment (+OM). Enrichment was performed by adding $92 \mathrm{~g}$ labile OM (finely ground fish feed, Ecolife, Dansk Ørredfoder, with 49.4\% DW POC, $8.1 \%$ DW total nitrogen organic $\mathrm{N}(\mathrm{TN}), 0.9 \% \mathrm{DW}$ total $\mathrm{P}(\mathrm{TP}))$ to $20 \mathrm{~L}$ of sediment. The enrichment corresponded to $26 \mathrm{~mol} \mathrm{POC} \mathrm{m}^{-2}$, which is comparable to the annual OM deposition at fish or mussel farms (Callier et al., 2006; Holmer et al., 2007; SanzLazaro et al., 2011a).

Sediment was packed into 36 core liners $(8 \mathrm{~cm}$ internal diameter - i.d.; $35 \mathrm{~cm}$ sediment depth) which were distributed into three tanks maintained at 16,22 or $26^{\circ} \mathrm{C}$ containing $65 \mathrm{~L} \mathrm{GF} / \mathrm{F}$-filtered seawater from Fæn $\varnothing$ Sund with a salinity of 17 psu. Each tank contained six cores of each -OM and $+\mathrm{OM}$, sediment. The $16^{\circ} \mathrm{C}$ treatment was chosen as the reference level of present mean SST for summer months in temperate areas of the Baltic Sea (Kristensen 1993; Holmer and Kristensen 1996). The 22 and $26^{\circ} \mathrm{C}$ treatments were chosen as SST climate change scenarios in 60 and 100 years based on the SST temperature rise observed in the last decades (Mackenzie and Schiedek 2007; Belkin, 2009) and expected 
rises (Doscher and Meier, 2004; $1^{\circ} \mathrm{C}$ per decade in both cases).

The sediment in the cores was left for 3 days to compact and acclimatize. Then three $N$. diversicolor were added to each core to simulate the natural density (Delefosse et al., 2012). The time of polychaete addition was assumed to be the beginning of the experiment $(t=0)$. $N$. diversicolor bioirrigation rates were previously reported in Sanz-Lázaro et al. (2011b). They were calculated based on $\mathrm{Br}^{-}$-addition experiments and were on average $13-24 \mathrm{~L} \mathrm{~m}^{-2} \mathrm{~d}^{-1}$ in the different treatments. There were no significant $(p<0.05)$ effects of temperature or of OM enrichment on bioirrigation rates and all cores were bioirrigated to a depth of 6-8 cm (SanzLazaro et al., 2011b). Bioirrigation rates in the present experiment were similar to the bioirrigation measured previously for other polychaetes (Quintana et al., 2013), and they were within the range of the bioirrigation performed by natural macrofaunal communities (Valdemarsen et al., 2010). Unfortunately irrigation rates and visual observations showed that the added worms died in three $+\mathrm{OM}$ cores at $26^{\circ} \mathrm{C}$, and results from these cores were omitted from further analysis. For the rest of the cores no polychaetes were found dead during the experiment, and active $N$. diversicolor were observed in all the rest of the cores. The bromide incubations indicated that $N$. diversicolor ventilated their burrows with the same intensity regardless of OM-enrichment level.

Additionally, six cores with $5 \mathrm{~cm}$ i.d. were also filled with $-\mathrm{OM}$ and +OM sediment to determine initial element pools in the sediment. Cores were closed at the bottom with rubber stoppers and $\sim 20 \mathrm{~cm}$ sediment was added, leaving a 10$12 \mathrm{~cm}$ headspace above the sediment. During the experiment the water in each tank was kept aerated and changed every week. The cores were kept submerged and in darkness throughout the experiment (25-39 days). More specific details can be found in Sanz-Lázaro et al. (2011b).

\subsection{Nutrient fluxes}

$\mathrm{NH}_{4}^{+}$and $\mathrm{PO}_{4}^{3-}$ fluxes between sediment and water were measured every 2-4 days during the first 2 weeks and every week during the rest of the experiment. During flux measurements, the water column of each sediment core was sampled and cores were closed with rubber stoppers. Incubations were ended after $3-5 \mathrm{~h}(-\mathrm{OM})$ or $1-2 \mathrm{~h}(+\mathrm{OM})$, when the rubber stoppers were removed and the water column was sampled again. All samples were GF/F-filtered, transferred to $20 \mathrm{~mL}$ plastic vials and frozen $\left(-20^{\circ} \mathrm{C}\right)$.

\subsection{Sectioning of cores}

The three $5 \mathrm{~cm}$ i.d. sediment cores of each sediment type $(-\mathrm{OM}$ and $+\mathrm{OM})$ were initially sectioned $(t=0$; henceforth referred to as initial cores), and the remaining cores from every temperature treatment were sectioned at the end of the experiment (henceforth, final cores). Cores were sectioned

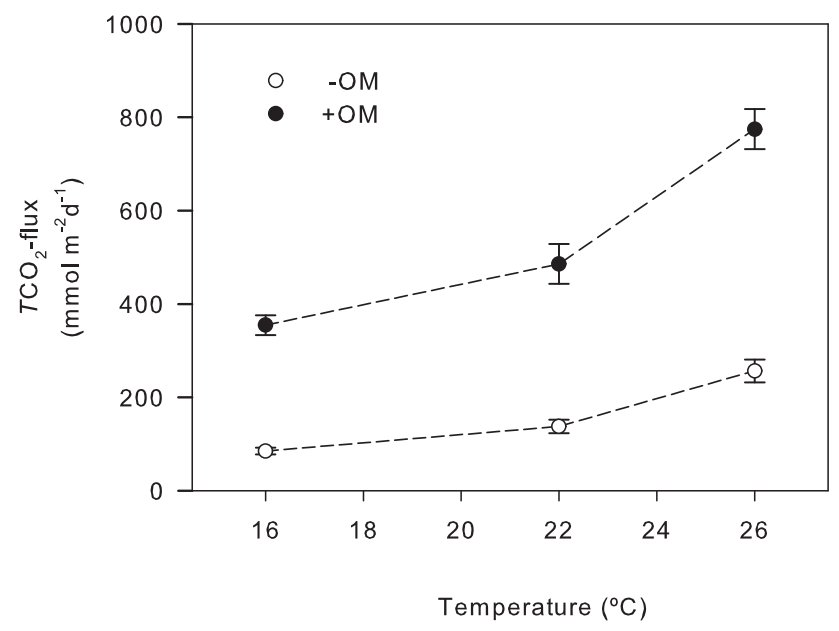

Figure 1. Mineralization rates, shown as flux rates of total $\mathrm{CO}_{2}$ (mean \pm SE, $n=6$ ) versus temperature under nonorganically $(-\mathrm{OM})$ and organically polluted $(+\mathrm{OM})$ conditions modified from Sanz-Lázaro et al. (2011b). Lines are shown to visualize the trajectory but do not represent a regression.

into $1 \mathrm{~cm}$ slices up to a depth of $2 \mathrm{~cm}$ and into $2 \mathrm{~cm}$ slices up to a depth of $16 \mathrm{~cm}$. Every sediment slice was homogenized and subsampled for different analyses. One subsample from each sediment slice was used to measure reactive $\mathrm{Fe}$ and phosphate bound to reactive Fe. A subsample of sediment was used for TP measurement. The remaining sediment from each slice was used to determine TN, sediment density and water content. All analytical methods are described below. Since temperature has a strong stimulatory effect on microbial reaction rates, the duration of the temperature treatments varied to prevent porewater sulfate depletion and a shift in sediment metabolism towards methanogenesis. Thus, the sectioning of the sediments at 16,22 and $26^{\circ} \mathrm{C}$ was performed after 39,32 and 25 days, respectively.

\subsection{Sediment metabolic rates}

$\mathrm{C}$ mineralization rates were estimated as time-integrated total $\mathrm{CO}_{2}\left(T \mathrm{CO}_{2}\right)$ sediment-water-column flux divided by the experiment duration, as described in Sanz-Lázaro et al. (2011b; Fig. 1). $T \mathrm{CO}_{2}$ fluxes were measured following the same procedures as for nutrient fluxes and $T \mathrm{CO}_{2}$ concentration was analyzed by flow injection analysis (Hall and Aller, 1992).

\subsection{Analyses}

$\mathrm{NH}_{4}^{+}$and $\mathrm{PO}_{4}^{3-}$ were analyzed spectrophotometrically on a Lachat QuikChem 8500 autoanalyzer. Reactive Fe was extracted on $\sim 0.2 \mathrm{~g}$ of sediment subsamples with $5 \mathrm{~mL}$ of $0.5 \mathrm{M} \mathrm{HCl}$ shaken for $30 \mathrm{~min}$. Then samples were centrifuged for $5 \mathrm{~min}(3000 \mathrm{rpm}$, ca. $1000 \times \mathrm{g})$ and GF/F filtered. The supernatant was analyzed by the ferrozine method (Stookey, 1970). Fe(II) was determined on the untreated extract, while 
Table 1. Depth-integrated $(0-16 \mathrm{~cm})$ pools of $\mathrm{P}$ and $\mathrm{N}$ (mean $\pm \mathrm{SE})$ in the sediment used in the experiment $(n=3$, initial concentration) and the estimates of the amount of nutrient mineralized during the experiment based on nutrient sediment-water-column fluxes $(n=6)$. Values in square brackets indicate the percentage of the nutrient mineralized out of the total added.

\begin{tabular}{|c|c|c|c|c|}
\hline & \multirow[t]{2}{*}{$\begin{array}{l}\text { Initial concentration } \\
\qquad\left(\mathrm{mmol} \mathrm{m}{ }^{-2}\right)\end{array}$} & \multicolumn{3}{|c|}{$\begin{array}{c}\text { Mineralized }\left(\mathrm{mmol} \mathrm{m}^{-2}\right), \\
\text { by temperature }\end{array}$} \\
\hline & & $16^{\circ} \mathrm{C}$ & $22^{\circ} \mathrm{C}$ & $26^{\circ} \mathrm{C}$ \\
\hline \multicolumn{5}{|c|}{$-\mathrm{OM}$} \\
\hline $\mathrm{P}$ & $8178 \pm 548$ & $2.65 \pm 1.12$ & $4.35 \pm 1.71$ & $5.64 \pm 1.42$ \\
\hline $\mathrm{N}$ & $7662 \pm 401$ & $252 \pm 57.5$ & $141 \pm 59.3$ & $441 \pm 138$ \\
\hline \multicolumn{5}{|c|}{$+\mathrm{OM}$} \\
\hline $\mathrm{P}$ & $8205 \pm 72.1$ & $7.54 \pm 1.33[4.2]$ & $13.54 \pm 2.4[7.6]$ & $16.49 \pm 2.24[9.3]$ \\
\hline $\mathrm{N}$ & $9854 \pm 292$ & $641 \pm 130$ [17.9] & $623 \pm 121[17.4]$ & $721 \pm 165[20.1]$ \\
\hline \multicolumn{5}{|c|}{$\begin{array}{l}\text { Notes: The } 16^{\circ} \mathrm{C} \text { treatment corresponds to the present mean sea surface temperature (SST) for summer months in the } \\
\text { Baltic Sea. The } 22 \text { and } 26^{\circ} \mathrm{C} \text { treatments were chosen as SST climate change scenarios in } 60 \text { and } 100 \text { years based on SST } \\
\text { temperature rise observed in the last decades and expected rises }\left(1{ }^{\circ} \mathrm{C} \text { per decade in both cases). - OM and +OM }\right. \\
\text { correspond to nonorganically and organically polluted treatments, respectively. The organic matter addition to }+\mathrm{OM} \text { cores } \\
\text { corresponded to } 26 \text { mol POC m }{ }^{-2} \text {, which is comparable to the annual organic matter deposition in areas under the } \\
\text { influence of mussel or fish farms. The final cores were maintained at } 16,22 \text { or } 26^{\circ} \mathrm{C} \text { in separate tanks containing filtered } \\
\text { seawater. }\end{array}$} \\
\hline
\end{tabular}

total $\mathrm{Fe}(\mathrm{Fe}(\mathrm{II})+\mathrm{Fe}(\mathrm{III}))$ was determined after reduction with hydroxylamine (Lovley and Phillips, 1987). Fe(III) was determined as the difference between total $\mathrm{Fe}$ and $\mathrm{Fe}(\mathrm{II}) . \mathrm{PO}_{4}^{3-}$ in $\mathrm{HCl}$ extracts was also analyzed spectrophotometrically after the addition of Molybdate reagent (Koroleff, 1983) to get a measure of Fe-bound P. Total $\mathrm{P}$ was determined on combusted sediment subsamples $\left(520^{\circ} \mathrm{C}, 2 \mathrm{~h}\right)$, which were boiled in $1 \mathrm{M} \mathrm{HCl}$ for $1 \mathrm{~h}$. The supernatant was analyzed for $\mathrm{PO}_{4}^{3-}$ as described above. TN was determined on a Carlo Erba CHN EA1108 elemental analyzer, following Kristensen and Andersen (1987). Sediment density was determined gravimetrically by weighing a known volume of sediment using cutoff syringes. Water content was measured as weight loss after drying $\left(105^{\circ} \mathrm{C},>12 \mathrm{~h}\right)$.

\subsection{Data analysis}

Significant differences in the content of solid-phase nutrients were tested by pair-wise $t$ tests. Comparisons were done between initial $-\mathrm{OM}$ and $+\mathrm{OM}$ cores and between the initial and each final treatment within each sediment type (-OM and +OM).

Average nutrient efflux rates were estimated as timeintegrated nutrient effluxes divided by the experiment duration. To compare the trends of the time-integrated effluxes between $-\mathrm{OM}$ and $+\mathrm{OM}$ treatments with temperature, we ran regression models considering temperature, the continuous covariate and $\mathrm{OM}$ enrichment as a fixed factor. According to the data on the trends of the time-integrated effluxes with increasing temperature, we considered different regression models. We used the second-order Akaike information criterion (AICc) to choose the best model, since it is a good compromise between fitting and the complexity of the model and it is recommended when the sample size is relatively low (Burnham and Anderson, 2002). In all regressions temperature was centered at $26^{\circ} \mathrm{C}$, so intercepts showed mean values of effluxes at this temperature. The significance of the regression coefficients was tested by ANOVA. Homoscedasticity was checked using Levene's test and normality with $\mathrm{p}-\mathrm{p}$ plots. Analyses were run in R (v. 2.15.0), and linear regressions were implemented using the $1 \mathrm{~m}$ function (R Development Core Team, 2012). All data were reported as mean \pm standard error (SE), and statistical tests were conducted with a significance level of $\alpha=0.05$.

We calculated the molar ratio of $\mathrm{C}: \mathrm{N}: \mathrm{P}$ in the added $\mathrm{OM}$ based on its composition and calculated the molar $\mathrm{C}: \mathrm{N}: \mathrm{P}$ ratio in the sediment based on $\mathrm{POC}, \mathrm{TN}$ and $\mathrm{TP}$ content in unenriched and enriched sediment. We estimated $\mathrm{C}: \mathrm{N}: \mathrm{P}$ ratios of organic matter being mineralized based on $T \mathrm{CO}_{2}$, $\mathrm{NH}_{4}^{+}$and $\mathrm{PO}_{4}^{3-}$ effluxes. $\mathrm{C}$ and $T \mathrm{CO}_{2}$ effluxes were reported in Sanz-Lázaro et al. (2011b).

\section{Results}

\subsection{P in sediment}

TP concentration in initial $-\mathrm{OM}$ and +OM sediment showed similar values (Table 1). The initial enrichment with fish feed should have resulted TP that was $0.4 \mathrm{~mol} \mathrm{~m}^{-2}$ higher in $+\mathrm{OM}$ cores than in $-\mathrm{OM}$ cores $(4.7 \%$ of the TP in the sediment), but this was not evident from our measurements, probably due to high variability between subsamples. Hence, there were no detectable differences in the TP content between initial $-\mathrm{OM}$ and $+\mathrm{OM}$ cores $(p>0.05)$. Additionally, there were no significant differences in TP content between 
Table 2. Depth-integrated $(0-16 \mathrm{~cm})$ pools of reactive $\mathrm{Fe}(\mathrm{III})$ and $\mathrm{P}$ bound to reactive $\mathrm{Fe}(\mathrm{mean} \pm \mathrm{SE})$ for initial cores $(n=3)$ and final cores $(n=6)$. See notes below Table 1 for explanation of treatments.

\begin{tabular}{lcccc}
\hline & $\begin{array}{c}\text { Initial concentration } \\
\left(\mathrm{mol} \mathrm{m}^{-2}\right)\end{array}$ & \multicolumn{3}{c}{$\begin{array}{c}\text { Final concentration }\left(\mathrm{mol} \mathrm{m}^{-2}\right), \\
\text { by temperature }\end{array}$} \\
\cline { 3 - 5 } & & $16^{\circ} \mathrm{C}$ & $22{ }^{\circ} \mathrm{C}$ & $26^{\circ} \mathrm{C}$ \\
\hline$-\mathrm{OM}$ & & & & \\
\hline Reactive $\mathrm{Fe}(\mathrm{III})$ & $2.5 \pm 0.1$ & $2.0 \pm 0.3$ & $1.8 \pm 0.1$ & $2.3 \pm 0.5$ \\
P bound to $\mathrm{Fe}$ & $2.5 \pm 0.1$ & $2.1 \pm 0.2$ & $2.5 \pm 0.2$ & $2.6 \pm 0.3$ \\
\hline$+\mathrm{OM}$ & & & & \\
\hline Reactive $\mathrm{Fe}(\mathrm{III})$ & $2.3 \pm 0.2$ & $1.9 \pm 0.2$ & $2.5 \pm 0.3$ & $2.3 \pm 0.5$ \\
P bound to $\mathrm{Fe}$ & $2.1 \pm 0.2$ & $2.4 \pm 0.2$ & $2.6 \pm 0.3$ & $2.0 \pm 0.2$ \\
\hline
\end{tabular}
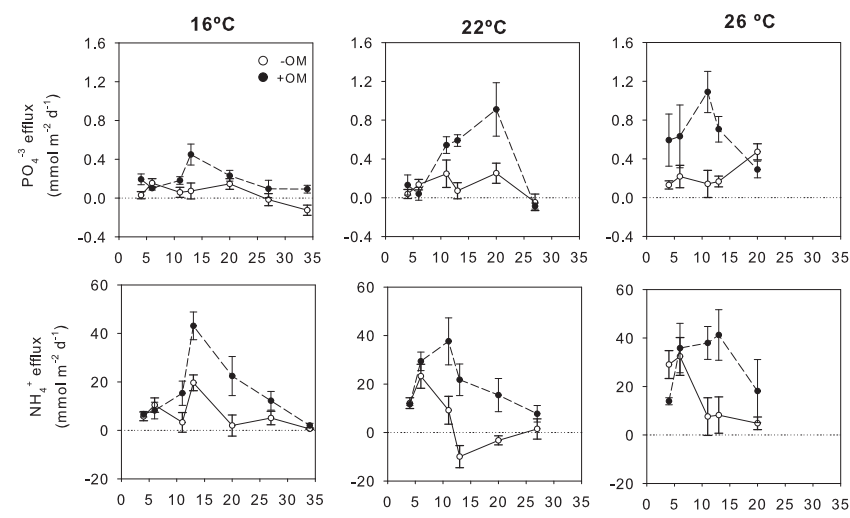

Time (d)

Figure 2. $\mathrm{PO}_{4}^{3-}$ and $\mathrm{NH}_{4}^{+}$efflux rates $(n=6$, mean $\pm \mathrm{SE})$ during the experiment at the three temperature scenarios under nonorganic $(-\mathrm{OM})$ and organic enrichment $(+\mathrm{OM})$ conditions. Dotted lines are the line of reference corresponding to 0 .

the initial and each final treatment within each sediment type ( $-\mathrm{OM}$ and $+\mathrm{OM})$. Fe-bound $\mathrm{P}$ at the beginning of the experiment also showed similar values in $-\mathrm{OM}$ and $+\mathrm{OM}$ cores (Table 2).

\section{2 $\mathrm{N}$ in sediment}

PON (particulate organic nitrogen) content in initial $-\mathrm{OM}$ cores was significantly lower $(p<0.05)$ than in + OM cores. Additionally, there were no significant differences in PON content between the initial and each final treatment within each sediment type ( $-\mathrm{OM}$ and $+\mathrm{OM})$. The initial enrichment with fish feed should have resulted in an extra $3.6 \mathrm{~mol} \mathrm{~m}^{-2}$ ( $46.8 \%$ of the PON concentration in the sediment), which would have been close to the measured enrichment $(28.6 \%$ of the PON in the sediment; Table 1$)$.

\subsection{Fe in sediment}

Pools of reactive $\mathrm{Fe}(\mathrm{III})$ were very similar between initial $-\mathrm{OM}$ and $+\mathrm{OM}$ cores, as well as between treatments at the end of the experiment (Table 2). Fe(III) concentration was always high in the first centimeter of the sediment in all treatments but also showed a high variability, ranging from $35.5 \pm 4.3$ to $12.7 \pm 3.6 \mu \mathrm{mol} \mathrm{cm} \mathrm{c}^{-3}$.

\subsection{Nutrient release}

$\mathrm{PO}_{4}^{3-}$ efflux showed a similar temporal pattern in the different treatments: an increase in the first days, a peak at intermediate stages and then decreasing effluxes towards the end (Fig. 2). The peaks of $\mathrm{PO}_{4}^{3-}$ efflux were stimulated by OM enrichment and temperature. Average $\mathrm{PO}_{4}^{3-}$ efflux showed a linear increasing trend with temperature in both $-\mathrm{OM}$ and $+\mathrm{OM}$ cores (Fig. 3a). The AICc showed that $\mathrm{PO}_{4}^{3-}$ effluxes were best fitted with a linear regression (Table A1). The regression analysis showed that average $\mathrm{PO}_{4}^{3-}$ efflux increased linearly with temperature $(p<0.05)$ in $-\mathrm{OM}$ and $+\mathrm{OM}$ cores. There were significant differences between $-\mathrm{OM}$ and $+\mathrm{OM}$ treatments at $26^{\circ} \mathrm{C}(p<0.05)$, and the significant interaction term of the regression $(p<0.05)$ indicated a steeper temperature response in $+\mathrm{OM}$ compared to $-\mathrm{OM}$ treatments (Table 3).

The overall trend of $\mathrm{NH}_{4}^{+}$efflux was similar to $\mathrm{PO}_{4}^{3-}$ efflux. $\mathrm{NH}_{4}^{+}$effluxes increased at the beginning, peaked and then decreased towards the end (Fig. 2). The range of the $\mathrm{NH}_{4}^{+}$effluxes was stimulated by both organic enrichment and temperature. The trend of average $\mathrm{NH}_{4}^{+}$effluxes over the whole experiment was not as clear as for $\mathrm{PO}_{4}^{3-}$ effluxes (Fig. 3b). $\mathrm{NH}_{4}^{+}$effluxes were clearly stimulated at $26^{\circ} \mathrm{C}$ in both sediment types, however. According to the AICc, the trend of $\mathrm{NH}_{4}^{+}$efflux over temperature was best fitted with an exponential regression (Table A1). The regression analysis showed significant increasing $\mathrm{NH}_{4}^{+}$effluxes with temperature following a nonlinear trajectory $(p<0.05)$ in both $-\mathrm{OM}$ 
Table 3. Coefficients (means at $26^{\circ} \mathrm{C}$ ) of the regression model for $\mathrm{PO}_{4}^{3-}$ and $\mathrm{NH}_{4}^{+}$sediment-water-column flux (i.e., efflux) rates with temperature for nonorganically polluted (-OM) and organically polluted $(+\mathrm{OM})$ treatments. Regression model for $\mathrm{PO}_{4}^{3-}$ corresponds to a first-order polynomial regression, while for $\mathrm{NH}_{4}^{+}$it corresponds to an exponential regression (Table A1). Significant effects $(p<0.05)$ are indicated in bold.

\begin{tabular}{lrr}
\hline & $\mathrm{PO}_{4}^{3-}$ efflux rate & $\mathrm{NH}_{4}^{+}$efflux rate \\
\cline { 2 - 3 } & Coefficient $(\mathrm{SE})$ & Coefficient $(\mathrm{SE})$ \\
\hline Intercept & $\mathbf{0 . 2 0 7}(0.047)$ & $\mathbf{1 3 . 5 8}(3.26)$ \\
OM & $\mathbf{0 . 4 2 0}(0.076)$ & $\mathbf{1 2 . 4 5}(5.27)$ \\
Temperature & $\mathbf{0 . 0 1 6}(0.008)$ & $\mathbf{0 . 9 4 6}(0.524)$ \\
OM x Temperature & $\mathbf{0 . 0 2 8}(0.012)$ & $0.108(0.803)$ \\
\hline
\end{tabular}

and $+\mathrm{OM}$ sediment. There were significant differences between $-\mathrm{OM}$ and $+\mathrm{OM}$ treatments at $26^{\circ} \mathrm{C}(p<0.05)$. The interaction term of the regression did not show significant differences. Thus, $\mathrm{NH}_{4}^{+}$efflux in $-\mathrm{OM}$ and $+\mathrm{OM}$ cores followed a similar trend with temperature although at different ranges (Table 3).

Temperature increase enhanced $\mathrm{PO}_{4}^{3-}$ and $\mathrm{NH}_{4}^{+}$effluxes, especially in +OM cores, but the amount of total mineralized $\mathrm{PO}_{4}^{3-}$ and $\mathrm{NH}_{4}^{+}$only corresponded to $\sim 10$ and $\sim 20 \%$, respectively, of initial $\mathrm{P}$ and $\mathrm{N}$ in the different treatments (Table 1).

\section{5 $\mathrm{C}: \mathrm{N}: \mathrm{P}$ ratios}

The $\mathrm{C}: \mathrm{N}, \mathrm{C}: \mathrm{P}$ and $\mathrm{N}: \mathrm{P}$ ratios of the added $\mathrm{OM}$ were 5.2 , 21.3 and 4.1 , respectively. $\mathrm{C}: \mathrm{N}, \mathrm{C}: \mathrm{P}$ and $\mathrm{N}: \mathrm{P}$ ratios were similar in the initial $-\mathrm{OM}$ and $+\mathrm{OM}$ cores. The ratios of $\mathrm{C}$, $\mathrm{N}$ and $\mathrm{P}$ at the end of the experiment were calculated based on $\mathrm{CO}_{2}, \mathrm{NH}_{4}^{+}$and $\mathrm{PO}_{4}^{3-}$ effluxes. $\mathrm{C}: \mathrm{N}, \mathrm{C}: \mathrm{P}$ and $\mathrm{N}: \mathrm{P}$ ratios at the end of the experiment were generally greater in -OM than in $+\mathrm{OM}$ cores, although there was no clear trend with temperature treatments (Table 4).

\section{Discussion}

Our results show that temperature rise resulted in different trends in sediment nutrient release of $\mathrm{PO}_{4}^{3-}$ and $\mathrm{NH}_{4}^{+}$ under both organic and nonorganic enrichment conditions. While sediment $\mathrm{PO}_{4}^{3-}$ release followed a linear trend with increasing temperature, the $\mathrm{NH}_{4}^{+}$release from sediment show nonlinear trends, notably increasing when temperature increments were above $6^{\circ} \mathrm{C}$.

\section{1 $\mathrm{PO}_{4}^{3-}$ release}

The measured $\mathrm{PO}_{4}^{3-}$ effluxes at $16^{\circ} \mathrm{C}$ were within the range of effluxes measured in coastal sediments in the Baltic Sea (Sundby et al., 1992; Jensen et al., 1995). $\mathrm{PO}_{4}^{3-}$ effluxes in-
Table 4. Initial $\mathrm{C}: \mathrm{N}: \mathrm{P}$ ratios of the organic matter in the sediment, estimated from particulate organic carbon, total nitrogen and total phosphorus and overall $\mathrm{C}: \mathrm{N}: \mathrm{P}$ ratios estimated from nutrient and total $\mathrm{CO}_{2}$ flux over the experimental period. $\mathrm{C}$ and total $\mathrm{CO}_{2}$ flux data were reported in Sanz-Lázaro et al. (2011b). See notes below Table 1 for explanation of treatments.

\begin{tabular}{lcccc}
\hline & $\begin{array}{c}\text { Initial ratio } \\
\text { in the sediment }\end{array}$ & \multicolumn{3}{c}{$\begin{array}{c}\text { Overall ratio of the effluxes, } \\
\text { by temperature }\end{array}$} \\
\cline { 3 - 5 } & & $16^{\circ} \mathrm{C}$ & $22^{\circ} \mathrm{C}$ & $26{ }^{\circ} \mathrm{C}$ \\
\hline$-\mathrm{OM}$ & & & & \\
\hline $\mathrm{C}: \mathrm{N}$ & 12.7 & 13.3 & 25.3 & 15.1 \\
$\mathrm{C}: \mathrm{P}$ & 11.6 & 849 & 656 & 988 \\
$\mathrm{~N}: \mathrm{P}$ & 0.9 & 63.8 & 25.9 & 65.3 \\
\hline$+\mathrm{OM}$ & & & & \\
\hline $\mathrm{C}: \mathrm{N}$ & 11.6 & 21.6 & 25.0 & 26.8 \\
$\mathrm{C}: \mathrm{P}$ & 13.5 & 1866 & 1157 & 1174 \\
$\mathrm{~N}: \mathrm{P}$ & 1.2 & 86.5 & 46.3 & 43.7 \\
\hline
\end{tabular}

creased linearly with temperature in both $-\mathrm{OM}$ and $+\mathrm{OM}$ treatments, but the slope of the regression was significantly steeper in $+\mathrm{OM}$ cores compared to - OM cores. This suggests that the temperature-dependent increase in $\mathrm{PO}_{4}^{3-}$ effluxes is enhanced by $\mathrm{OM}$ enrichment. The temperature effect on $\mathrm{PO}_{4}^{3-}$ release was comparable to the temperature effect on total $\mathrm{C}$ metabolism in both organically enriched and nonorganically enriched conditions (Sanz-Lazaro et al., 2011b). However, the release of $\mathrm{PO}_{4}^{3-}$ was much lower than that of $T \mathrm{CO}_{2}$, as indicated by high $\mathrm{C}: \mathrm{P}$ ratios. suggesting that organic $\mathrm{P}$ was either less labile compared to organic $\mathrm{C}$ or that inorganic $\mathrm{PO}_{4}^{3-}$ was retained in the sediment to a larger extent than C. Taking into account that the added OM (fish feed) is highly labile, our data suggest $\mathrm{PO}_{4}^{3-}$ retention in the sediment, which could be associated with adsorption to oxidized forms of Fe (Jensen et al., 1995).

$\mathrm{P}$ retention in marine sediments is controlled by the forms of $\mathrm{P}, \mathrm{Fe}$ and $\mathrm{S}$ in the sediment, by interactions between these pools, and by the sediment redox conditions (Roden and Edmonds, 1997; Gachter and Muller, 2003). Generally, in sediments with an oxic surface layer, oxidized $\mathrm{Fe}$ acts as a lid for $\mathrm{PO}_{4}^{3-}$, which is adsorbed to ferric $\mathrm{Fe}$, preventing its release into the water column (Rozan et al., 2002). In this experiment, the $\mathrm{PO}_{4}^{3-}$ binding capacity was not easily exhausted due to the large pool of $\mathrm{Fe}$ (III) (tens of millimoles) in the first centimeter of the sediment. This explanation was also supported by the fact that the levels of $\mathrm{PO}_{4}^{3-}$ bound to $\mathrm{Fe}$ (III) showed low variation between initial and final cores. The oxic conditions of the sediment surface were maintained in all treatments despite metabolism enhancement and a subsequent increase in sulfide production, which was especially notable in the +OM treatments. The continuous oxygenation of surface sediment due to $N$. diversicolor bioturbation 

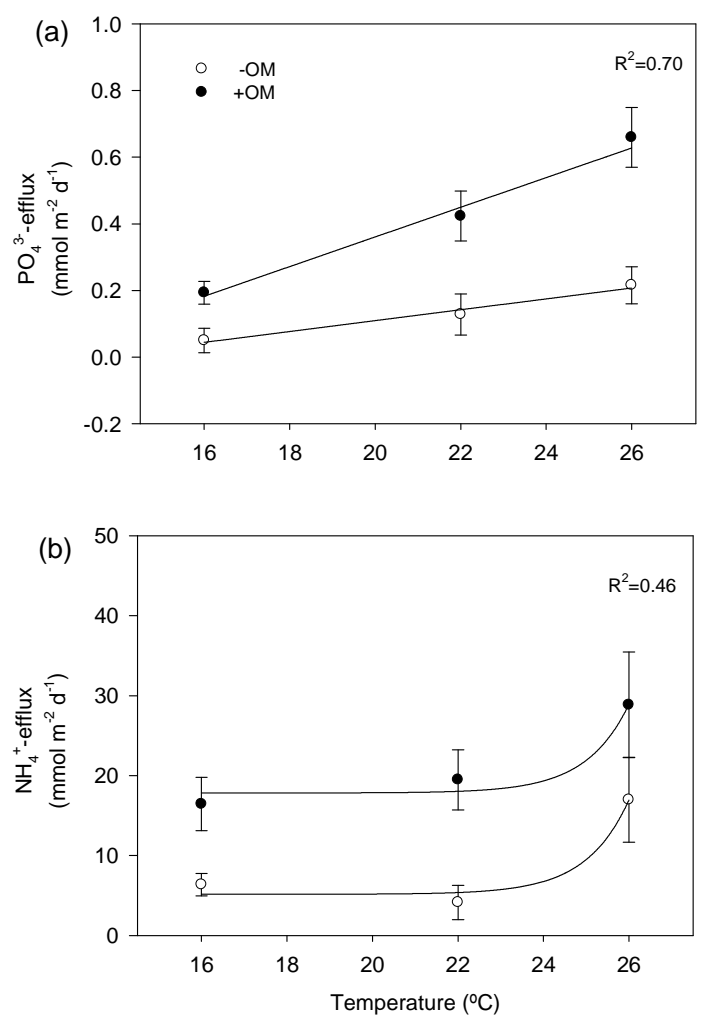

Figure 3. Nutrient sediment-water-column flux rates $(n=6$, mean $\pm \mathrm{SE}$ ) versus temperature under nonorganically (-OM) and organically polluted $(+\mathrm{OM})$ conditions. Lines indicate significant $(p<0.05)$ regressions for $-\mathrm{OM}$ and $+\mathrm{OM}$ treatments. Type of regression was chosen according to the AICc (corrected Akaike information criterion; Table A1). $R^{2}$ refers to the whole regression model for each nutrient, which includes the factor OM.

and bioirrigation (Sanz-Lazaro et al., 2011b) was probably critical for maintaining an oxic sediment surface with high $\mathrm{Fe}$ (III) concentrations, since dramatically stimulated sediment metabolism is expected to notably diminish the Fe(III) pool of the sediment in the absence of macrofauna (Valdemarsen et al., 2009). All these results suggest that the capacity of the sediment to retain $\mathrm{PO}_{4}^{3-}$ was maintained despite high metabolic rates due to organic enrichment and elevated temperatures.

The $\mathrm{PO}_{4}^{3-}$ retention may be diminished in sediments with a low pool of Fe(III) (Rozan et al., 2002) and/or with no bioturbating macrofauna (Bartoli et al., 2009). Hence, under such conditions the $\mathrm{PO}_{4}^{3-}$ efflux could be much higher than measured in this experiment. A longer experiment could also have resulted in decreased $\mathrm{PO}_{4}^{3-}$ retention because of the exhaustion of the binding sites of $\mathrm{PO}_{4}^{3-}$ with $\mathrm{Fe}$ (III) (Jorgensen, 1996). Nevertheless, the capacity of the sediment to retain $\mathrm{PO}_{4}^{3-}$ is notable considering that the amount of OM added in this experiment corresponded to the total OM deposited on the seabed below fish farms during a year, and that the OM added has a high reactivity, which implies that most of the
$\mathrm{OM}$ is mineralized initially. Thus, marine sediment can act as a relevant sink of $\mathrm{P}$, even under severe scenarios of temperature rise and organic enrichment, as long as it has a large enough pool of $\mathrm{Fe}$ and the macrofauna keeps the surface of the sediment under oxic conditions.

\section{2 $\mathrm{NH}_{4}^{+}$release}

Rates of $\mathrm{NH}_{4}^{+}$effluxes at $16^{\circ} \mathrm{C}$ were within the range reported from previous laboratory experiments at similar conditions with non-enriched or enriched sediment (Valdemarsen et al., 2009, 2010). The 2-4-fold stimulation of $\mathrm{NH}_{4}^{+}$ efflux due to temperature rise was in the same range observed in sediments from coastal areas (i.e., a temperature rise of ca. $10^{\circ} \mathrm{C}$ during summer resulted in 2- to 4 -fold increases in $\mathrm{NH}_{4}^{+}$efflux; Kristensen, 1993). As with $\mathrm{PO}_{4}^{3-}$, the release rates of $\mathrm{NH}_{4}^{+}$were always higher in $+\mathrm{OM}$ cores than in $-\mathrm{OM}$ treatments for a given temperature, highlighting that $\mathrm{OM}$ enrichment had a stimulatory effect on $\mathrm{NH}_{4}^{+}$release. This was expected since high $\mathrm{NH}_{4}^{+}$release is often observed in sediments enriched with labile organic matter (Christensen et al., 2000; Valdemarsen et al., 2012). $\mathrm{NH}_{4}^{+}$release was not stimulated by a temperature between 16 and $22^{\circ} \mathrm{C}$, but above $22^{\circ} \mathrm{C} \mathrm{NH}_{4}^{+}$release increased nonlinearly in both - OM and $+\mathrm{OM}$ treatments. The notable increase in $\mathrm{NH}_{4}^{+}$release at a temperature increment of $10^{\circ} \mathrm{C}$ in both $-\mathrm{OM}$ and $+\mathrm{OM}$ treatments led us to speculate that the efficiency of $\mathrm{NH}_{4}^{+}$oxidizing pathways is lowered at high temperatures; nevertheless, the data of $\mathrm{C}: \mathrm{N}$ ratios pointed to an opposite hypothesis.

The $\mathrm{C}: \mathrm{N}$ ratios of $\mathrm{C}$ and $\mathrm{N}$ release during the experiment were always higher than the $\mathrm{C}: \mathrm{N}$ ratios of the sediment $\mathrm{OM}$, in particular when the temperature rise was high. This suggests that part of the mineralized $\mathrm{N}$ is not released to the water column as $\mathrm{NH}_{4}^{+}$but is transformed into other $\mathrm{N}$ compounds. $\mathrm{NH}_{4}^{+}$could be nitrified in the oxidized surface sediment or in $N$. diversicolor burrows and subsequently reduced to $\mathrm{N}_{2}$ via anammox or denitrification (Thamdrup, 2012). Previous studies show that both denitrification and anammox are stimulated by increasing temperatures (Nowicki, 1994; Alsterberg et al., 2012; Canion et al., 2014) and by the availability of OM (Nowicki, 1994; Thamdrup and Dalsgaard, 2002; Engstrom et al., 2005), which supports the data from this experiment. Nevertheless, evidence based on $\mathrm{NO}_{3}^{-}$ and $\mathrm{NO}_{2}^{-}$data are needed to confirm this hypothesis. Despite this, $\mathrm{NH}_{4}^{+}$is the dominant form of dissolved inorganic $\mathrm{N}$ effluxing from organically enriched sediments (Christensen et al., 2000; Holmer et al., 2003), while coupled nitrificationdenitrification rarely exceeds $1-2 \mathrm{mmol} \mathrm{m}^{-2} \mathrm{~d}^{-1}$ in marine sediments (Middelburg et al., 1996). We are therefore confident that the $\mathrm{NH}_{4}^{+}$release rates can act as a proxy for total inorganic $\mathrm{N}$ release to the water column.

Despite the fact that bioturbation and bioirrigation by macrofauna promote $\mathrm{OM}$ mineralization, in the present ex- 
periment both $\mathrm{PO}_{4}^{3-}$ and $\mathrm{NH}_{4}^{+}$effluxes were below the expected levels of the mineralized organic matter. In the case of $\mathrm{PO}_{4}^{3-}$, this can be explained by the $\mathrm{PO}_{4}^{3-}$ retention capacity of the sediment that is promoted by macrofauna activity (Bartoli et al., 2009). In the case of $\mathrm{NH}_{4}^{+}$, these results could be explained because macrofauna promotes $\mathrm{NH}_{4}^{+}$-oxidizing processes and the coupling between nitrification and denitrification (Gilbert et al., 1995). Thus, sediment reworking processes of macrofauna promote nutrient recycling while preventing eutrophication.

Additionally it should be considered that the experiment was performed in darkness, as the experiment was designed to simulate the generally low availability of light at the sediment surface in relatively enclosed and shallow coastal areas exposed to eutrophication, such as in the Danish coastal areas. Nevertheless, in other areas with more light availability autotrophic processes are also important. This could lead to different results with regards to nutrient release rates from the sediment.
In conclusion, in future scenarios of climate change, sediment $\mathrm{PO}_{4}^{3-}$ release is expected to increase following the trends observed for $\mathrm{OM}$ mineralization rates in the sediment. The magnitude of the release of $\mathrm{PO}_{4}^{3-}$ is influenced not only by local OM deposition rates but also by sediment characteristics, particularly the amount of reactive Fe in sediment. $\mathrm{NH}_{4}^{+}$release from sediment is not expected to increase substantially with temperature increments of up to $6^{\circ} \mathrm{C}$, in organically polluted and in nonpolluted sediments. However, more severe temperature rises may be associated with a nonlinear increase in the release of $\mathrm{NH}_{4}^{+}$from sediments. As most marine basins are $\mathrm{N}$-limited, the excess release of $\mathrm{NH}_{4}^{+}$ may set in motion a cascade of negative effects leading to deteriorating environmental quality. These effects are expected to be more detrimental in organically polluted areas and in coastal basins with no or restricted exchange with ocean waters. 
Appendix A

Table A1. AICc (corrected Akaike information criterion) of the different regression models for $\mathrm{PO}_{4}^{3-}$ and $\mathrm{NH}_{4}^{+}$efflux rates.

\begin{tabular}{|c|c|c|}
\hline & \multicolumn{2}{|c|}{$\mathrm{AICc}$} \\
\hline & $\mathrm{PO}_{4}^{3-}$ efflux rates & $\mathrm{NH}_{4}^{+}$efflux rates \\
\hline$y_{i}=\beta_{0}+\beta_{1} x_{i}$ & -31.940 & 247.60 \\
\hline$y_{i}=\beta_{0}+\beta_{1} e^{x_{i}}$ & -23.032 & 243.04 \\
\hline$y_{i}=\beta_{0}+\beta_{1} x_{i}+\beta_{2} x_{i}^{2}$ & -26.321 & 248.63 \\
\hline$y_{i}=\beta_{0}+\beta_{1} \frac{1}{x_{i}}$ & -30.336 & 248.95 \\
\hline
\end{tabular}




\section{The Supplement related to this article is available online at doi:10.5194/bg-12-4565-2015-supplement.}

Acknowledgements. The authors are grateful to the technicians at Økolab, Department of Biology, University of Southern Denmark, for their help with the chemical analysis. CS was supported by the Ministerio de Educación y Ciencia of Spain. We thank the referees for helping to improve the manuscript with their suggestions.

Edited by: T. Treude

\section{References}

Alsterberg, C., Sundback K., and Hulth S.: Functioning of a Shallow-Water Sediment System during Experimental Warming and Nutrient Enrichment, Plos One, 7, e51503, 2012.

Bartoli, M., Longhi D., Nizzoli D., Como S., Magni P., and Viaroli P.: Short term effects of hypoxia and bioturbation on solute fluxes, denitrification and buffering capacity in a shallow dystrophic pond, J. Exp. Mar. Biol. Ecol., 381, 105-113, 2009.

Belkin, I. M.: Rapid warming of Large Marine Ecosystems, Prog. Oceanogr., 81, 207-213, 2009.

Burnham, K. P. and Anderson D. R.: Model Selection and Multimodel Inference: A Practical Information-Theoretic Approach Springer-Verlag, 2002.

Callier, M. D., Weise A. M., McKindsey C. W., and Desrosiers G.: Sedimentation rates in a suspended mussel farm (Great-Entry Lagoon, Canada): biodeposit production and dispersion, Mar. Ecol.-Prog. Ser., 322, 129-141, 2006.

Canion, A., Kostka, J. E., Gihring, T. M., Huettel, M., van Beusekom, J. E. E., Gao, H., Lavik, G., and Kuypers, M. M. M.: Temperature response of denitrification and anammox reveals the adaptation of microbial communities to in situ temperatures in permeable marine sediments that span $50^{\circ}$ in latitude, Biogeosciences, 11, 309-320, doi:10.5194/bg-11-309-2014, 2014.

Christensen, P. B., Rysgaard S., Sloth N. P., Dalsgaard T., and Schwaerter S.: Sediment mineralization, nutrient fluxes, denitrification and dissimilatory nitrate reduction to ammonium in an estuarine fjord with sea cage trout farms, Aquat. Microb. Ecol., 21, 73-84, 2000.

Conley, D. J., Bjorck S., Bonsdorff E., Carstensen J., Destouni G., Gustafsson B. G., Hietanen S., Kortekaas M., Kuosa H., Meier H. E. M., Muller-Karulis B., Nordberg K., Norkko A., Nurnberg G., Pitkanen H., Rabalais N. N., Rosenberg R., Savchuk O. P., Slomp C. P., Voss M., Wulff F., and Zillen L.: Hypoxia-Related Processes in the Baltic Sea, Environ. Sci. Technol., 43, 34123420, 2009.

Cowan, J. L. W. and Boynton W. R.: Sediment-water oxygen and nutrient exchanges along the longitudinal axis of Chesapeake Bay: Seasonal patterns, controlling factors and ecological significance, Estuaries, 19, 562-580, 1996.

Delefosse, M., Banta G. T., Canal-Verges P., Penha-Lopes G., Quintana C. O., Valdemarsen T., and Kristensen E.: Macrobenthic community response to the Marenzelleria viridis (Polychaeta) invasion of a Danish estuary, Mar. Ecol.-Prog. Ser, 461, 83-94, 2012.
Doscher, R. and Meier H. E. M.: Simulated sea surface temperature and heat fluxes in different climates of the Baltic Sea, Ambio, 33, 242-248, 2004.

Engstrom, P., Dalsgaard T., Hulth S., and Aller R. C.: Anaerobic ammonium oxidation by nitrite (anammox): Implications for $\mathrm{N}$ 2 production in coastal marine sediments, Geochim. Cosmochim. Ac., 69, 2057-2065, 2005.

Falkenberg, L. J., Connell S. D., and Russell B. D.: Disrupting the effects of synergies between stressors: improved water quality dampens the effects of future $\mathrm{CO}_{2}$ on a marine habitat, J. Appl. Ecol., 50, 51-58, 2013.

Gachter, R. and Muller B.: Why the phosphorus retention of lakes does not necessarily depend on the oxygen supply to their sediment surface, Limnol. Oceanogr., 48, 929-933, 2003.

Gilbert, F., Bonin P., and Stora G.: Effect of Bioturbation on Denitrification in A Marine Sediment from the West Mediterranean Littoral, Hydrobiologia, 304, 49-58, 1995.

Gray, J. S., Wu R. S., and Or Y. Y.: Effects of hypoxia and organic enrichment on the coastal marine environment, Mar. Ecol.-Prog. Ser, 238, 249-279, 2002.

Hall, P. O. and Aller R. C.: Rapid, Small-Volume, Flow-Injection Analysis for Sigma- $\mathrm{CO}_{2}$ and $\mathrm{NH}_{4}^{+}$in Marine and Fresh-Waters, Limnol. Oceanogr., 37, 1113-1119, 1992.

Halpern, B. S., Walbridge S., Selkoe K. A., Kappel C. V., Micheli F., D’Agrosa C., Bruno J. F., Casey K. S., Ebert C., Fox H. E., Fujita R., Heinemann D., Lenihan H. S., Madin E. M. P., Perry M. T., Selig E. R., Spalding M., Steneck R., and Watson R.: A global map of human impact on marine ecosystems, Science, 319, 948 952, 2008 .

Holmer, M. and Kristensen E.: Seasonality of sulfate reduction and pore water solutes in a marine fish farm sediment: The importance of temperature and sedimentary organic matter, Biogeochemistry, 32, 15-39, 1996.

Holmer, M., Duarte C. M., Heilskov A., Olesen B., and Terrados J.: Biogeochemical conditions in sediments enriched by organic matter from net-pen fish farms in the Bolinao area, Philippines, Mar. Pollut. Bull., 46, 1470-1479, 2003.

Holmer, M., Marbà N., Díaz-Almela E., Duarte C. M., Tsapakis M., and Danovaro R.: Sedimentation of organic matter from fish farms in oligotrophic Mediterranean assessed through bulk and stable isotope (delta C-13 and delta $\mathrm{N}-15$ ) analyses, Aquaculture, 262, 268-280, 2007.

IPCC.: Climate Change 2007: Synthesis Report Cambridge University Press, Cambridge, 2007.

Islam, M. S. and Tanaka M.: Impacts of pollution on coastal and marine ecosystems including coastal and marine fisheries and approach for management: a review and synthesis, Mar. Pollut. Bull., 48, 624-649, 2004.

Jensen, H. S., Mortensen P. B., Andersen F. O., Rasmussen E., and Jensen A.: Phosphorus Cycling in A Coastal Marine Sediment, Aarhus Bay, Denmark, Limnol. Oceanogr., 40, 908-917, 1995.

Jorgensen, B. B.: Processes at the sediment-water interface, in: The major biogeochemical cycles and their interactions, edited by: Bolin, B. and Cook, K. B., John Wiley and Sons, Chichester, UK, 477-515, 1983.

Jorgensen, B. B.: Material flux in the sediment, in:Eutrophication in coastal marine ecosystems, edited by: Jorgensen, B. B. and Richardson, K.: American Geophysical Union, Washington, DC, 115-135, 1996. 
Kelly, J. R., Berounsky V. M., Nixon S. W., and Oviatt C. A.: Benthic-Pelagic Coupling and Nutrient Cycling Across An Experimental Eutrophication Gradient, Mar. Ecol.-Prog. Ser, 26, 207-219, 1985.

Koroleff, F.: Determination of nutrients, in: Methods of seawater analysis, edited by: Grasshof, K., Ehrhardt, M., and Kremling, K.: Verlag Chemie, Weinheim, 125-187, 1983.

Kristensen, E.: Seasonal variations in benthic community metabolism and nitrogen dynamics in a shallow, organicpoor lagoon, Estuar. Coast. Shelf Sci., 36, 565-586, 1993.

Kristensen, E.: Organic matter diagenesis at the oxic/anoxic interface in coastal marine sediments, with emphasis on the role of burrowing animals, Hydrobiologia, 426, 1-24, 2000.

Kristensen, E. and Andersen F. O.: Determination of OrganicCarbon in Marine-Sediments - A Comparison of 2 Chn-Analyzer Methods, J. Exp. Mar. Biol. Ecol., 109, 15-23, 1987.

Lovley, D. R. and Phillips E. J. P.: Rapid Assay for Microbially Reducible Ferric Iron in Aquatic Sediments, Appl. Environ. Microbiol., 53, 1536-1540, 1987.

Mackenzie, B. R. and Schiedek D.: Daily ocean monitoring since the 1860 s shows record warming of northern European seas, Global Change Biol., 13, 1335-1347, 2007.

Meier, H. E. M., Eilola K., and Almroth E.: Climate-related changes in marine ecosystems simulated with a 3-dimensional coupled physical-biogeochemical model of the Baltic Sea, Clim. Res., 48, 31-55, 2011.

Mermillod-Blondin, F., Rosenberg R., Francois-Carcaillet F., Norling K., and Mauclaire L.: Influence of bioturbation by three benthic infaunal species on microbial communities and biogeochemical processes in marine sediment, Aquat. Microb. Ecol., 36, 271-284, 2004.

Middelburg, J. J., Soetaert K., and Herman P. M. J.: Empirical relationships for use in global diagenetic models, Deep-Sea Res., 44, 327-344, 1997.

Middelburg, J. J., Soetaert K., Herman P. M. J., and Heip C. H. R.: Denitrification in marine sediments: A model study, Global Biogeochem. Cy., 10, 661-673, 1996.

Nixon, S. W.: Remineralization and nutrient cycling in coastal marine ecosystems Springer, 1981.

Nowicki, B. L.: The effect of temperature, oxygen, salinity, and nutrient enrichment on estuarine denitrification rates measured with a modified nitrogen gas flux technique, Estuar. Coast. Shelf Sci., 38, 137-156, 1994.

Quintana, C. O., Kristensen E., and Valdemarsen T.: Impact of the invasive polychaete Marenzelleria viridis on the biogeochemistry of sandy marine sediments, Biogeochemistry, 115, 95-109, 2013.

R Development Core Team.: R: A language and environment for statistical computing, reference index version 2.15.0 R Foundation for Statistical Computing, Vienna, Austria, 2012.
Robador, A., Bruchert V., and Jorgensen B. B.: The impact of temperature change on the activity and community composition of sulfate-reducing bacteria in arctic versus temperate marine sediments, Environ. Microbiol., 11, 1692-1703, 2009.

Roden, E. E. and Edmonds J. W.: Phosphate mobilization in ironrich anaerobic sediments: Microbial Fe(III) oxide reduction versus iron-sulfide formation, Archiv fur Hydrobiologie, 139, 347 378, 1997.

Rozan, T. F., Taillefert M., Trouwborst R. E., Glazer B. T., Ma S., Herszage J., Valdes L. M., Price K. S., and Luther III, G. W.: Iron-sulfur-phosphorus cycling in the sediments of a shallow coastal bay: Implications for sediment nutrient release and benthic macroalgal blooms, Limnol. Oceanogr., 47, 1346-1354, 2002.

Sanz-Lazaro, C., Belando M. D., Marín-Guirao L., Navarrete-Mier F., and Marín A.: Relationship between sedimentation rates and benthic impact on Maërl beds derived from fish farming in the Mediterranean, Mar. Environ. Res., 71, 22-30, 2011 a.

Sanz-Lazaro, C., Valdemarsen T., Marin A., and Holmer M.: Effect of temperature on biogeochemistry of marine organic-enriched systems: implications in a global warming scenario, Ecol. Appl., 21, 2664-2677, 2011b.

Stookey, L. L.: Ferrozine - A New Spectrophotometric Reagent for Iron, Anal. Chem., 42, 779-781, 1970.

Sundby, B., Gobeil C., Silverberg N., and Mucci A.: The phosphorus cycle in coastal marine sediments, Limnol. Oceanogr., 11291145, 1992.

Thamdrup, B.: New Pathways and Processes in the Global Nitrogen Cycle, Annu. Rev. Ecol. Evol. S., 43, 407-428, 2012.

Thamdrup, B. and Dalsgaard T.: Production of N-2 through anaerobic ammonium oxidation coupled to nitrate reduction in marine sediments, Appl. Environ. Microbiol., 68, 1312-1318, 2002.

Thamdrup, B. and T. Dalsgaard.: Nitrogen Cycling in Sediments, in: Microbial Ecology of the Oceans, edited by: Kirchman, D L., John Wiley and Sons, Hoboken, New Jersey, USA, 527-568, 2008.

Valdemarsen, T., Kristensen E., and Holmer M.: Metabolic threshold and sulfide-buffering in diffusion controlled marine sediments impacted by continuous organic enrichment, Biogeochemistry, 95, 335-353, 2009.

Valdemarsen, T., Kristensen E., and Holmer M.: Sulfur, carbon, and nitrogen cycling in faunated marine sediments impacted by repeated organic enrichment, Mar. Ecol.-Prog. Ser., 400, 37-53, 2010.

Valdemarsen, T., Bannister R. J., Hansen P. K., Holmer M., and Ervik A.: Biogeochemical malfunctioning in sediments beneath a deep-water fish farm, Environ. Pollut., 170, 15-25, 2012. 